ПСИХОЛОГІЧНІ ОСОБЛИВОСТІ УЯВЛЕНЬ ПРО НЕБЕЗПЕКУ ОСІБ, ЯКІ ПРОЖИВАЮТЬ НА ТЕРИТОРІЯХ РІЗНОГО РІВНЯ УРБАНІЗОВАНОСТІ

\title{
PSYCHOLOGICAL FEATURES OF DANGER PERCEPTIONS OF PERSONS LIVING IN THE TERRITORY OF VARIOUS DEGREE OF URBANIZATION
}

У статті показана актуальність порівняльного аналізу психологічних особливостей уявлень про небезпеку осіб, які проживають на територіях різного рівня урбанізованості. мета дослідження полягає в емпіричному дослідженні відмінностей психологічних особливостей уявлень про небезпеку осіб, які проживають у сільській та міській місцевості. Представлено якісний та кількісний аналіз уявлень (асоціативних рядів) про поняття «небезпека» у осіб, які проживають в селі або місті. Наразі гостро постає питання вивчення особливостей адаптації людини до швидких і раптових змін життя, а також рівня готовності до таких змін. Постійні трансорормації сучасного суспільства нині є неминучим супутником життя кожної людини, проте часто такі зміни в уявленнях людей постають джерелом загроз. 3 огляду на че було висунуте припущення про те, що існує відмінність в уявленнях про небезпеку у осіб, які проживають у сільській та міській місцевості. Подано результати емпіричного вивчення психологічних особливостей уявлень про небезпеку у осіб, які проживають у сільській та міській місцевості. Наведено порівняльний аналіз уявлень про поняття «небезпека» за групами асоціацій у осіб, які проживають в селі або у місті. Встановлено, що асоціації до стимулу «небезпека» мають статистично значущі особливості. Угруповано слова-асоиіаціі за показниками, які репрезентуються у таких полярних діадах: соціальна - індивідуальна значущість, об'єктність - суб'єктність .

Встановлено, що існують відмінності в асоціаціях, які продукують респонденти, що проживають на територіях із різним рівнем урбанізованості. Визначено, що спостерігається спільне для більшості респондентів загальне уявлення про небезпеку. Таке уявлення описується через арективну складову, тобто жителі сільської і міськоі територій асоціюють поняття «небезпека» із страхом. Визначено, що страх як основна асоціація послідовно спостерігається і у перших асоціаціях, і у більш глибоких - останніх. Показано, що детальний аналіз дозволяє встановити відмінності у відповідях респондентів. Встановлено, що респондентам, які мешкають в сільській місцевості, притаманне сприймання небезпеки через поняття, які описують або абстрактні явища, або непереборні сили зовнішніх фокторів (вогонь, пожежа), а жителям міст притаманне сприймання через поняття емоційного або ж соціально спрямованого характеру (тривога, загроза, війна, хвороба, паніка). Показано, що існують статистично значущі відмінності в уявленнях про небезпеку осіб, які проживають на територіях різного рівня урбанізованості.
Ключові слова: безпека, небезпека, сільська місцевість, міська місцевість, уявлення про небезпеку, рівень урбанізованості.

The article shows the relevance of a comparative analysis of the psychological characteristics of the perceptions of the danger of persons living in territories of different levels of urbanization. So, the purpose of the study is to empirically study the differences in the psychological characteristics of the perceptions of the danger of persons living in rural and urban areas. A qualitative and quantitative analysis of ideas (associative series) about the concept of «danger» among people living in a village or city is presented.

Now there is an acute issue of studying the characteristics of human adaptation to rapid sudden changes in life and the level of readiness for such changes. Constant transformations of modern society are currently an inevitable companion in the life of every person, but often such changes in people's perceptions arise as a source of threats. Therefore, it was suggested that there is a difference in the perception of danger among people living in rural and urban areas. The article presents the results of an empirical study of the psychological characteristics of perceptions of dangers in people living in rural and urban areas. A comparative analysis of the ideas about the concept of "danger" by groups of associations among people living in a village or in a city is given. It was found that associations to the "danger" stimulus have statistically significant features. Groupings of word-associations according to indicators are presented in such polar dyads: social - individual significance and object-subjectivity.

It was found that there are differences in associations that are produced by respondents living in territories with different levels of urbanization. It was determined that there is a general idea of danger common for the majority of respondents, which is described through an affective component: residents of rural and urban areas primarily associate the concept of "danger" with fear. It has been determined that fear, as the main association, is consistently observed in the first associations, and in the deeper ones - the latter. It is shown that a detailed analysis makes it possible to establish differences in the answers of respondents. It was found that respondents living in rural areas are inherent in the perception of "danger" through a concept that describes either abstract phenomena, or the insurmountable forces of external factors (flame, fire), urban residents are inherent in perception through the concept of an emotional or socially-directed nature (anxiety, threat, war, disease, panic). It is shown that there are statistically significant differences in the perception of danger people live in territories of different levels of urbanization

Key words: safety, danger, rural area, urban area, perception of danger, level of urbanization. доцент кафедри психології

Поліський національний університет
2020-2021 роки засвідчили, що сучасна особистість постійно та систематично опиняється перед низкою різних економічних, соціальних, інформаційних, політичних викли- ків, які демонструють необхідність не лише психічної стійкості, а й здатності швидко та успішно пристосовуватися до трансформацій, що постійно втручаються в буденну 
свідомість людини. Отже, особистість змушена або вибудовувати своє життя таким чином, щоб уникнути небезпек, які постійно та неочікувано можуть чинити значний вплив на її вибудувану картину світу, або сприймати небезпеку як об'єктивну дійсність, яка є чинником або умовою організації життєдіяльності.

Можна стверджувати, що суб'єктивний рівень почуття власної небезпеки не $є$ окремим утворенням, а лише відображає актуальний стан особистості в певний момент часу та сигналізує про оточуючу дійсність та її рівень безпеки для людини, а також спрямовує та визначає її діяльність.

Для формування лабільного до постійних та різких різнопланових змін суспільства, які $€$ частиною його розвитку, необхідно зважати та брати до уваги особливості уявлень про безпеку та небезпеку (незахищеність) у осіб, які проживають у місцях різного рівня урбанізованості. Отже, можна припустити, що:

1) особи, які проживають на високоурбанізованих територіях, матимуть відмінні уявлення про небезпеку від тих, хто проживає на територіях із низьким рівнем урбанізованості;

2) суб'єктивний рівень небезпеки буде відрізнятись у осіб, які проживають на високоурбанізованих територіях, від тих, хто проживає на територіях із низьким рівнем урбанізованості.

Поняття «небезпека» та «безпека» в останні десятиліття стали об'єктом уваги науковців соціальних, політичних, економічних, інформаційних та психологічних наук. Зокрема, психологи досить широко розглядають поняття «безпека» та «небезпека» у різноманітних вимірах. Поняття «безпека», як правило, $€$ частиною досліджень, що стосуються взаємодії з іншими людьми (психологічної безпеки в закладах освіти, психологічної безпеки в інклюзивних середовищах, психологічної безпеки в екстремальних та особливих мовах) [4; 5; 8; 9]. Особливо актуальними напрямами $€$ дослідження особливостей безпечної поведінки та безпечного життя особистості [1; 2; 7]. Зокрема, Н.C. Уханова, аналізуючи поняття «безпека», вказує: «Із поняттям «безпека» асоціюється стан та почуття перебування в безпеці, відсутність тривоги чи стурбованості, упевненість, стабільність» [7, с. 92]. Розглядаючи феномен безпеки/небезпеки, психологи, як правило, описують саме безпеку та визначають її як описову характеристику актуальним станам особистості. На думку вчених, безпека - це відсутність загроз, стійкість, впевненість, стан фізичної, духовної, психологічної рівноваги [6]. Безпека розглядається як характеристика стану особистості. При цьому цей стан має такі досить чітко окреслені характеристики: сталість, здатність опиратися зовнішнім впливам, здатність швидкої рекре- ації, здатність до рефлексії, позитивне світобачення, усвідомлення власної значущості тощо [3, с. 373]. Водночас небезпека набагато рідше стає об'єктом наукового інтересу науковців. Опис психологічної небезпеки як явища психологічної дійсності має уривчастий характер та виражається як антонім психологічній безпеці [6; 7].

Явище психологічної небезпеки описують відносно вузько. Так, психологічну небезпеку розглядають як напруженість, невизначеність та потенційний або актуальний загрозливий стан особистості [10; 11]; як деструкцію особистості з можливістю подальшого відновлення або без неї [10; 11]. Проте існують погляди на джерела психологічної небезпеки. Розглядаються загальні джерела психологічної небезпеки - зовнішні (негативний вплив оточуючого природного або соціального середовища) та внутрішні (аутоагресія) чинники» [3, с. 375].

Однак дослідження у сфері вивчення психологічних особливостей уявлень про небезпеку осіб, які проживають на територіях різного рівня урбанізованості, поки що не мають системного та описового вигляду, що і зумовило вибір теми дослідження [10; 11]. Мета статті полягає у дослідженні психологічних особливостей уявлень про небезпеку осіб, які проживають на територіях різного рівня урбанізованості.

Дослідження психологічних особливостей уявлень про небезпеку осіб, які проживають на територіях різного рівня урбанізованості, здійснювалось як один із елементів фундаментального наукового проєкту вивчення особливостей психологічної безпеки особистості в умовах трансформацій сучасного суспільства [3, с. 369-377]. Організація дослідження відбувалась з серпня 2020 до жовтня 2020, онлайн-анкетування проводилось 3 жовтня 2020 до січня 2021 року. До дослідження були залучені респонденти, які проживають на територіях різного рівня урбанізованості $\left(\mathrm{N}_{\text {заг. }}=575\right)$, з них більшість $є$ жителями міст (72,4\%), які характеризуються відносно високим рівнем урбанізованості ( $\left.\mathrm{N}_{\text {міст. }}=427\right)$, жителі

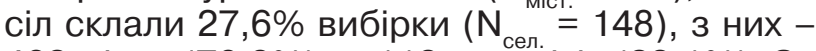
462 жінки (76,9\%) та 113 чоловіків (23,1\%). За віковим розподілом респондентів вибірка знаходиться в межах від 18 до 70 років, найбільшу частину становлять досліджувані віком 18-45 років (73\%), 105 респондентів віком 46-60 років $(19,1 \%)$ та 25 респондентів віком 61-70 років (4,9\%). Досліджувані $€$ жителями Житомирської (83\%), Київської (7\%), Вінницької (3\%), Дніпропетровської (2\%), Запорізької (2\%), Одеської (2\%) та Закарпатської (1\%) областей. Вказані вище характеристики вибірки дають підставу вважати, що вона $€$ репрезентативною та відображає на рівні 85,64\% населення держави. 
Для дослідження психологічних особливостей уявлень про небезпеку в осіб, які проживають на територіях різного рівня урбанізованості, учасникам дослідження було запропоновано упорядкований та систематизований перелік запитань до слова-стимулу «небезпека». Валідність та надійність опитувальника забезпечувалась за допомогою методу незалежних експертних оцінок. Опитувальник був складений із запитань, які були спрямовані на відчуття суб'єктивної безпеки та небезпеки у різноманітних сферах життя, а також створення 5-пунктного асоціативного ряду до слова-стимулу «небезпека».

Як і в основній частині дослідження [3], використовувались методи описової статистики та якісний аналіз отриманих результатів. Для якісного та кількісного аналізу асоціацій використано метод експертних оцінок. Для статистичної обробки одержаних кількісних даних застосовувались методи математичної статис- тики (описова статистика, порівняння залежних вибірок (t-критерій Стьюдента), ранговий кореляційний аналіз Спірмена). Автоматизована обробка даних проводилась за допомогою пакету програм IBM SPSS Statistics 26 та програмного середовища ArcGIS [3, с. 370].

У результаті проведення емпіричного дослідження була встановлена кількісна, якісна (смислова) специфіка та наповненість асоціацій до слова-стимулу «небезпека». Візуалізація результатів репрезентує, що респонденти, які мешкають на територіях різного рівня урбанізованості, слово-стимул «небезпека» описують через специфічні поняття, що мають певні закономірності (див. табл. 1).

За допомогою частотного аналізу встановлено, що загалом у вибірці спостерігається тенденція до виокремлення певних слів-відповідей на запропоновану асоціацію як у респондентів із міських територій, так і у жителів села. Так, у кожній із груп до слова-стимулу «небезпека» найчастіше зустрічається одна

Таблиця 1

Особливості асоціативних відповідей на слово-стимул “небезпека" у респондентів, які проживають на територіях із різним рівнем урбанізованості

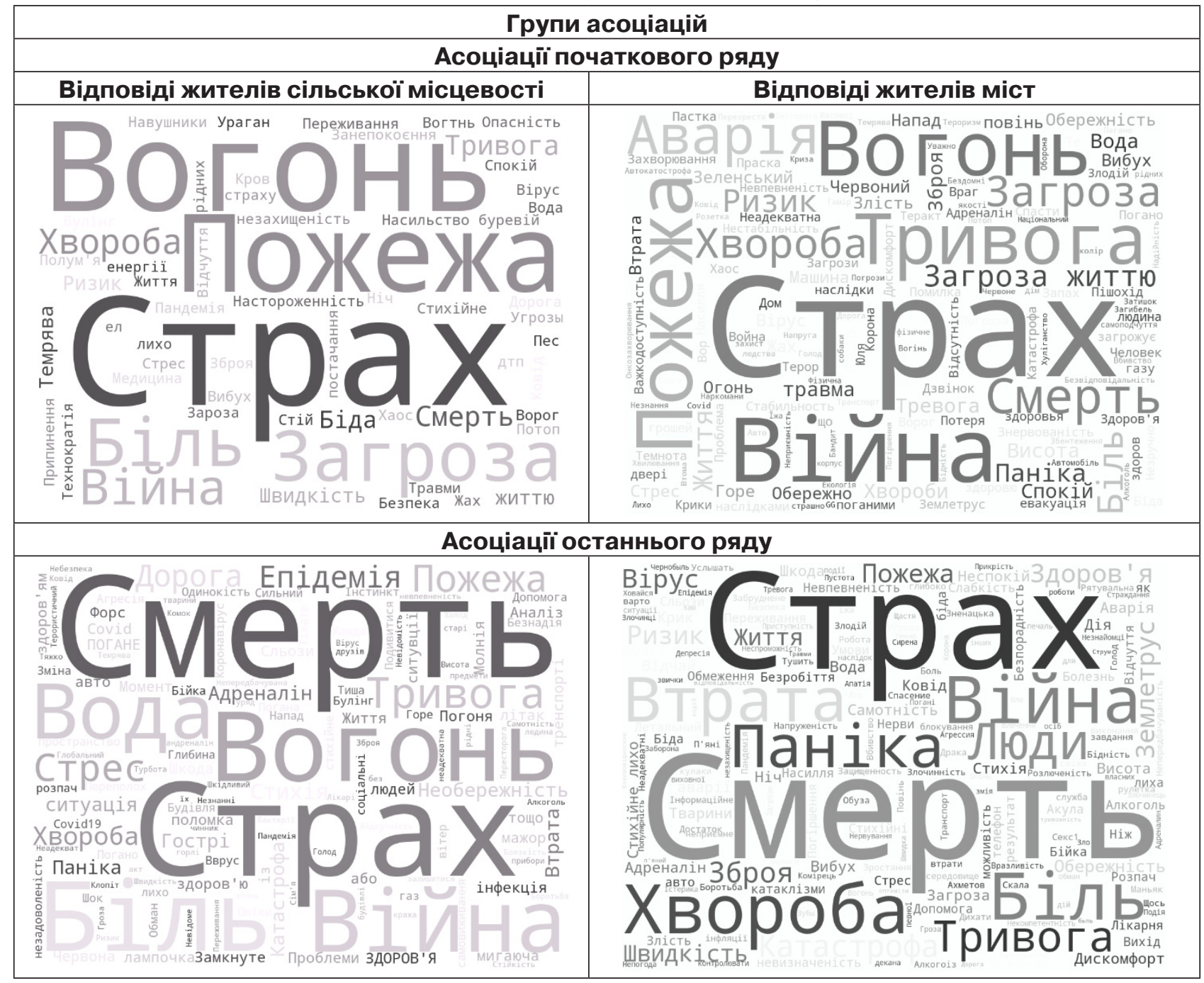


і та ж асоціація без суттєвих змін та перетворень - «страх» (37\%). Якщо продовжити частотну ієрархію, то можна встановити, що відповіді, які відображають афективну складову (емоції, почуття, стани, переживання), прослідковуються системно через такі ряди асоціацій: «тривога» (8\%), «паніка» $(4,4 \%)$, «злість» (1\%). Статистично значущими є лише вищевказані висловлювання, оскільки різноманіття словоформ є досить обмеженим.

У попередній частині дослідження [3] було показано, що існують особливості асоціативних рядів у респондентів із сільської місцевості: «Перші асоціації, які є зазвичай стереотипними, та останні, які відображають особистісно значущі асоціації, між собою не відрізняються. Для жителів сільської місцевості небезпека $€$ страхом, за яким криється щось невідоме та незрозуміле, що породжує нерозуміння та невпевненість. Встановлено, що існують статеві відмінності в уявленнях про небезпеку: чоловіки частіше асоціюють поняття «небезпека» із конкретними поняттями, жінки з абстрактними характеристиками та особистісно значущими категоріями. Визначено, що рівень суб'єктивного відчуття психологічної небезпеки у жінок значно вищий, ніж у чоловіків» [3, с. 373].

Також експертні оцінки дозволили встановити певні групи таких асоціацій: «абстрактні поняття», «особистісно значущі уявлення» та «конкретні поняття»» [3, с. 373]. Проте аналіз загальної вибірки вимагає внесення коректив у попередньо запропонований розподіл. Асоціативні ряди вибірки, у якій репрезентовані особи, які проживають на територіях із різним рівнем урбанізованості, дозволяє дещо систематизувати попередній розподіл. Так, виокремилися не лише групи, а і залежність між ними. Слова-асоціації були угруповані за показниками, які репрезентуються у таких полярних діадах: соціальна - індивідуальна значущість, об'єктність - суб'єктність.

Для переформатування відповідей респондентів із словесних у числові значення кожній асоціації із усіх чотирьох груп був присвоєний індекс. Числовий індекс встановлювався аналогічно до дослідження респондентів із сільської місцевості [3]. За допомогою методів математичної статистики було визначено, що респонденти, які проживають на територіях із різним рівнем урбанізованості, мають відмінності у асоціаціях першого (загального) порядку ( $t=4,172 ; p \leq 0,010)$ (див. табл. 2).

Встановлено, що респондентам, які мешкають в сільській місцевості, притаманне сприймання небезпеки через поняття, які описують або абстрактні явища, або непереборні сили зовнішніх факторів (вогонь, пожежа), жителям міст притаманне сприймання через поняття емоційного або ж соціально-спрямованого характеру (тривога, загроза, війна, хвороба, паніка). Проте виявились асоціації, які $є$ спільними для обох груп (смерть та страх). Очевидно, вони $€$ фундаментальною основою того, що дозволяє особистості оцінити ситуацію як таку, що уособлює однозначну неминучу небезпеку. Зарубіжні автори також наголошують на існуванні фундаментальних основ уявлення про небезпеку, які є глибшими, ніж наше усвідомлення безпеки чи благополуччя, оскільки стосуються не лише психічної, а й біологічної сфери [10;11].

Також було встановлено, що респонденти, які проживають на територіях із різним рівнем урбанізованості, мають відмінності у асоціаціях останнього (особистісного) порядку $(t=7,265 ; p \leq 0,004)$ (див. табл. 3).

Асоціації останнього ряду мають здебільшого особистісний характер, що зумовило високі показники значущості.

Для дослідження значущих відмінностей уявлень про небезпеку респондентів, які проживають на територіях різного рівня урбанізованості, був застосований t-критерій Стьюдента (див. табл. 4). Були виявлені статистично значущі відмінності у певних групах асоціацій. Так, існує відмінність у діаді «об'єктно-суб'єктна спрямованість». Статистично значущим показником є значення об'єктної спрямованості ( $t=8,628$; $p \leq 0,055)$, тобто для респондентів, які проживають у селі, явища оточуючої дійсності несуть більш відчутну загрозу, а для міських жителів таким джерелом небезпеки $€$ особистісно значущі явища та стани, вони $\epsilon$ значно інтеріоризованими ( $\mathrm{t}=5,442 ; \mathrm{p} \leq$ 0,021). У діаді «соціально-індивідуальна значущість» таких відмінностей не встановлено.

Для дослідження статистично значущих показників психологічних особливостей уяв-

Таблиця 2

Відмінності перших асоціацій до слова “небезпека" у респондентів, які проживають на територіях із різним рівнем урбанізованості

\begin{tabular}{|c|c|c|c|c|c|c|c|c|}
\hline \multicolumn{9}{|c|}{ Paired Samples Test } \\
\hline \multirow{4}{*}{$\begin{array}{l}\frac{0}{2} \\
\stackrel{0}{\sum} \\
0 \\
0 \\
0 \\
0\end{array}$} & \multicolumn{5}{|c|}{ Paired Differences } & \multirow{3}{*}{$t$} & \multirow{3}{*}{$\mathrm{df}$} & \multirow{3}{*}{$\begin{array}{l}\text { Sig. } \\
\text { 2-tailed }\end{array}$} \\
\hline & \multirow[t]{2}{*}{ Mean } & \multirow{2}{*}{$\begin{array}{c}\text { Std. } \\
\text { Deviation }\end{array}$} & \multirow{2}{*}{$\begin{array}{l}\text { Std. Error } \\
\text { Mean }\end{array}$} & \multicolumn{2}{|c|}{$\begin{array}{c}\text { 95\% Confidence Interval } \\
\text { of the Difference }\end{array}$} & & & \\
\hline & & & & Lower & Upper & & & \\
\hline & ,561 & ,936 & ,162 & ,699 & ,264 & 4,172 & 147 & ,010 \\
\hline
\end{tabular}


Відмінності останніх асоціацій до слова “небезпека" у респондентів,

Таблиця 3 які проживають на територіях із різним рівнем урбанізованості

\begin{tabular}{|c|c|c|c|c|c|c|c|c|}
\hline \multicolumn{9}{|c|}{ Paired Samples Test } \\
\hline \multirow{4}{*}{ 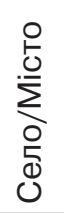 } & & & aired Diffe & nces & & \multirow{3}{*}{$\mathrm{t}$} & \multirow{3}{*}{ df } & \multirow{3}{*}{$\begin{array}{l}\text { Sig. } \\
\text { 2-tailed }\end{array}$} \\
\hline & \multirow[t]{2}{*}{ Mean } & \multirow{2}{*}{$\begin{array}{c}\text { Std. } \\
\text { Deviation }\end{array}$} & \multirow{2}{*}{$\begin{array}{l}\text { Std. Error } \\
\text { Mean }\end{array}$} & \multicolumn{2}{|c|}{$\begin{array}{l}\text { 95\% Confidence Interval of } \\
\text { the Difference }\end{array}$} & & & \\
\hline & & & & Lower & Upper & & & \\
\hline & 684 & ,919 & 093 &, 573 & ,193 & 7,265 & 426 & ,004 \\
\hline
\end{tabular}

Таблиця 4

Відмінності уявлень про небезпеку респондентів, які проживають на територіях різного рівня урбанізованості

\begin{tabular}{|c|c|c|c|c|c|c|c|c|}
\hline \multirow{3}{*}{ Групи асоціацій } & \multicolumn{5}{|c|}{ Paired Differences } & \multirow{3}{*}{$\mathbf{t}$} & \multirow{3}{*}{ df } & \multirow{3}{*}{$\begin{array}{c}\text { Sig. } \\
\text { 2-tailed }\end{array}$} \\
\hline & \multirow[t]{2}{*}{ Mean } & \multirow[t]{2}{*}{$\begin{array}{c}\text { Std. } \\
\text { Deviation }\end{array}$} & \multirow[t]{2}{*}{$\begin{array}{l}\text { Std. Error } \\
\text { Mean }\end{array}$} & \multicolumn{2}{|c|}{$\begin{array}{l}95 \% \text { Confidence } \\
\text { Interval of the } \\
\text { Difference }\end{array}$} & & & \\
\hline & & & & Lower & Upper & & & \\
\hline Соціально значущі & ,264 & 1,093 & ,254 &,- 578 & 1,225 & 1,075 & 107 & ,309 \\
\hline $\begin{array}{l}\text { Індивідуально } \\
\text { значущі }\end{array}$ & ,301 & 1,719 &, 093 &,- 982 & 1,210 & 1,832 & 69 &, 113 \\
\hline $\begin{array}{c}\text { Об’єктна } \\
\text { спрямованість }\end{array}$ & , 184 & 3,117 & ,017 &,- 256 & 4,986 & 8,628 & 297 &, 055 \\
\hline $\begin{array}{c}\text { Суб'єктна } \\
\text { спрямованість }\end{array}$ & 170 & 1,309 & ,065 &,- 883 & 3,004 & 5,442 & 101 &, 021 \\
\hline Загалом & ,098 & 2,183 & ,276 &,- 674 & 2,867 & 4,265 & 574 & 108 \\
\hline
\end{tabular}

лень про небезпеку осіб, які проживають на територіях різного рівня урбанізованості, було використано кореляційний аналіз Спірмена (див. табл. 5). Визначено статистично значущий зв'язок між показниками психологічної безпеки та деякими діадами асоціацій серед респондентів, які проживають на територіях із різним рівнем урбанізованості. Так, встановлено прямий зв'язок між соціально значущими асоціаціями та рівнем безпеки у жителів міст $(r=0,651 ; \rho \leq 0,001)$. Жителям сільської місцевості притаманні дещо інші показники. Вони схильні описувати небезпеку через поняття, які стосуються слів об'єктної спрямованості

Таблиця 5

Взаємозв'язки показників психологічної безпеки та груп домінуючих асоціацій

\begin{tabular}{|c|c|c|c|c|}
\hline \multicolumn{3}{|c|}{ Вибірка/групи асоціацій } & Безпека (C) & Безпека (M) \\
\hline \multirow{3}{*}{$\begin{array}{l}\text { Spearman's } \\
\text { rho }\end{array}$} & \multirow{3}{*}{ Загальна вибірка } & Correlation Coefficient & ,391 & ,208 \\
\hline & & Sig. (6-tailed) & ,209 & ,205 \\
\hline & & $\mathrm{N}$ & 148 & 427 \\
\hline \multirow{3}{*}{$\begin{array}{l}\text { Spearman's } \\
\text { rho }\end{array}$} & \multirow{3}{*}{ Соціально значущі } & Correlation Coefficient & ,285 & $651^{\star \star}$ \\
\hline & & Sig. (6-tailed) & ,056 & ,027 \\
\hline & & $\mathrm{N}$ & 40 & 67 \\
\hline \multirow{3}{*}{$\begin{array}{l}\text { Spearman's } \\
\text { rho }\end{array}$} & \multirow{3}{*}{ Індивідуально значущі } & Correlation Coefficient & , 168 & ,302 \\
\hline & & Sig. (6-tailed) & ,096 & ,085 \\
\hline & & $\mathrm{N}$ & 32 & 37 \\
\hline \multirow{3}{*}{$\begin{array}{l}\text { Spearman's } \\
\text { rho }\end{array}$} & \multirow{3}{*}{ Об'єктна спрямованість } & Correlation Coefficient &, $591^{*}$ & , 194 \\
\hline & & Sig. (6-tailed) & , 101 & ,055 \\
\hline & & $\mathrm{N}$ & 48 & 249 \\
\hline \multirow{3}{*}{$\begin{array}{l}\text { Spearman's } \\
\text { rho }\end{array}$} & \multirow{3}{*}{$\begin{array}{c}\text { Суб’єктна } \\
\text { спрямованість }\end{array}$} & Correlation Coefficient & ,119 & ,209 \\
\hline & & Sig. (6-tailed) & 021 & 119 \\
\hline & & $\mathrm{N}$ & 28 & 73 \\
\hline
\end{tabular}

** - Correlation is significant at the 0.001 level (6-tailed).

* - Correlation is significant at the 0.05 level (6-tailed). 
( $r=0,591 ; \rho \leq 0,05)$, суб'єктні ж (індивідуалістичні) значення їм не притаманні. Не спостерігаємо кореляцій у респондентів, у яких домінуючою групою є індивідуально значущі поняття.

За результатами дослідження встановлено, що суб'єктивний рівень особистої психологічної небезпеки та уявлення про небезпеку у осіб, які проживають в сільській та міській місцевості, мають певні особливості.

Отже, психологічну небезпеку варто розглядати системно, зокрема як уразливість перед впливами різноманітного характеру, перед якими особистість опиняється раптово та непідготовленою, як маркер змінних умов, які для особистості $є$ стресовими, як показник стійкості особистості перед викликами. Стрімкі трансформації суспільства та неперервні соціальні зміни сприймаються як загрози, від яких необхідно захиститись. Отже, необхідно підвищити суб'єктивний рівень почуття власної безпеки. Визначено особливості уявлень про поняття «небезпека» у осіб, які проживають у міській та сільській місцевості. Встановлено, що основними причинами небезпеки $є$ групи уявлень, які описують протилежні за смисловим наповненням пари понять. Це такі поняття: «соціальна - індивідуальна значущість», «об'єктність - суб'єктність». Визначено, що досліджувані, які проживають на високоурбанізованих територіях, мають відмінні уявлення про небезпеку від тих, хто проживає на територіях із низьким рівнем урбанізованості. Суб'єктивний рівень небезпеки відрізняється у респондентів, які проживають на високоурбанізованих територіях, від тих, хто проживає на територіях із низьким рівнем урбанізованості. Показано, що суб'єктивний рівень особистої психологічної небезпеки та уявлення про небезпеку в осіб, які проживають в сільській та міській місцевості, мають певні відмінності, які піддаються математичному моделюванню.

\section{ЛІТЕРАТУРА:}

1. Заграй Л.Д. Практики соціально-психологічного захисту особистості в умовах ризиків і небезпек. Психологічні перспективи. 2015. № 26. С. 133-142.
2. Ларіна Т.О. Психологічна небезпека комунікативних ризиків в процесі інсрормаційної взаємодії особистості. Інфрормаційно-цифрровий освітній простір України: транссрормаційні процеси і перспективи розвитку : матеріали методологічного семінару НАПН України. 4 квітня 2019 р., 2019. C. 345-353.

3. Литвинчук A.I. Психологічні особливості уявлень про небезпеку осіб, які проживають у сільській місцевості. Наукові перспективи. 2020. № 4 (10). С. 369-377. DOI: https://doi.org/10.52058/2708-7530-2021-4(10)-369-377.

4. Панченко Т.Л. Психологічна безпека інклюзивного освітнього середовища. Науковий часопис НПУ імені М.П. Драгоманова. Серія 19 «Корекційна педагогіка та спеціальна психологія». 2014. № 28. C. $327-332$.

5. Приходько І.І. Психологічна безпека персоналу екстремальних видів діяльності: концепція, транссрормаційна модель, методологія дослідження. Актуальні проблеми соціології, психології, педагогіки. 2015. № 4. С. 117-125.

6. Рощин С.К., Соснин В.А. Психологическая безопасность: новый подход к безопасности человека, общества и государства. Российский монитор. 1995. № 6. URL: www.bookap.by.ru/psywar/grachev/ gl6.shtm.

7. Уханова Н.С. Інсрормаційно-психологічна безпека особистості, суспільства та держави. Правова інформатика. 2013. № 3. С. 91-95.

8. Харченко А.С. Психологічна безпека особистості викладача вишу. Науковий вісник Львівського державного університету внутрішніх справ. Серія «Психологія» 2012. № 2. С. 443-450.

9. Яковенко С.I. Психологічна безпека працівників органів та підрозділів внутрішніх справ. Проблеми екстремальної та кризової психології. 2013. № 14 (1). C. 331-339.

10. Edmondson A.C. Psychological safety, trust, and learning in organizations: a group-level lens. In Trust and Distrust in Organizations: Dilemmas and Approaches, ed. R.M. Kramer, K.S. Cook, 2004. pp. 239-72. New York: Russell Sage.

11. Soares, André Escórcio \& Lopes, Miguel Pereira Social networks and psychological safety: A model of contagion. Journal of Industrial Engineering and Management (JIEM). URL: http://hdl.handle.net/ 10419/188640. 